\title{
KDR wt Allele
}

National Cancer Institute

\section{Source}

National Cancer Institute. KDR wt Allele. NCI Thesaurus. Code C52172.

Human KDR wild-type allele is located within $4 q 11-q 12$ and is approximately $47 \mathrm{~kb}$ in length. This allele, which encodes vascular endothelial growth factor receptor 2 protein, plays a role in vascular development, regulation of vascular permeability and VEGF signal transduction. 